\title{
Использование микросферной фотолитографии для селективного синтеза полупроводниковых структур группы А3B5 на Si
}

\author{
Л.Н. Дворецкая ${ }^{1}$, А.М. Можаров ${ }^{1}$, В.В. Фёдоров ${ }^{1}$, И.С. Мухин ${ }^{1,2}$ \\ ${ }^{1}$ СПбАУ РАН, Академический университет, 194021, Санкт-Петербург, ул. Хлопина, 8к3 \\ ${ }^{2}$ Университет ИТМО, 197101, Санкт-Петербург, Кронверкский пр., 49 \\ тел:+7 (931) 346-2429, эл.nочта: Liliyabutler@gmail.com
}

DOI 10.34077/RCSP2021-83

Рост материалов группы $\mathrm{A}_{3} \mathrm{~B}_{5}$ на рассогласованных по параметру решетки подложках $\mathrm{Si}$, как правило, приводит к образованию дислокаций [1]. Для получения материал более высокого совершенства используют текстурированные пластины для последующей селективной эпитаксии [2]. Это обеспечивает эффективную релаксацию механических напряжений в синтезируемых слоях. Данный подход приводит к формированию структур более высокого кристаллического совершенства. В качестве материала маски используют оксид кремния, на котором ввиду термодинамических условий не происходит зарождения полупроводниковых структур группы $\mathrm{A}_{3} \mathrm{~B}_{5}$ [3].

На сегодняшний день, для создания текстурированного слоя оксида кремния на $\mathrm{Si}$ подложках среди прочих подходов используют метод литографии электронным пучком с последующим травлением слоя оксида кремния. При этом метод электронной литографии непригоден для производства наноструктур на больших площадях. В данной работе будет продемонстрирован метод создания подложек для селективной эпитаксии с использованием микросферной фотолитографии, позволяющей создавать гексагональные массивы наноструктур на больших площадях. Выбирая диаметр микросферических частиц и задавая дозу экспонирования на этапе фотолитографии по микросферам, появляется возможность контролируемого варьирования диаметра и периода отверстий в маске. Подобные маски могут быть использованы при синтезе различных эпитаксиальных наноструктур, таких как нитевидные нанокристаллы, наноколонки, нанодиски и др. При этом, такой подход к подготовке ростовых подложек позволяет не только обеспечить текстурирование пластин большой площади, но и существенно сократить время экспонирования резиста.

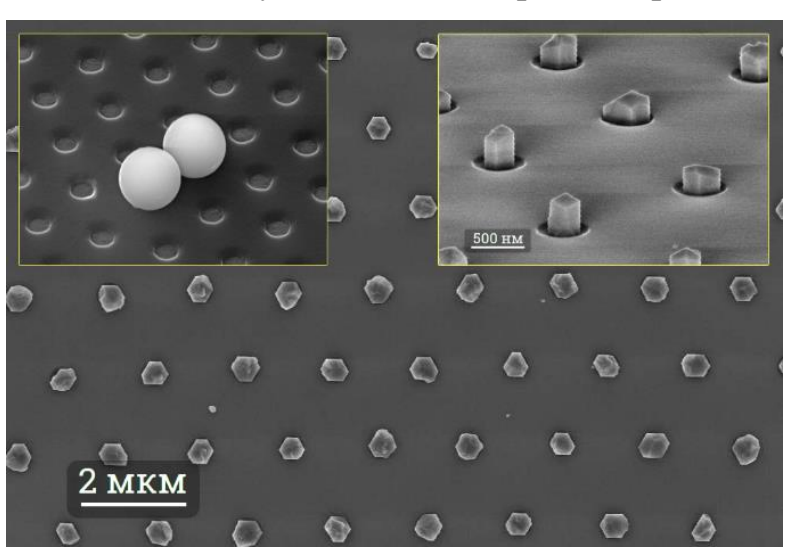

В качестве примера использования данного метода будут продемонстрированы синтезированные структуры группы $\mathrm{A}_{3} \mathrm{~B}_{5}$ в виде наноколонок и нитевидных нанокристаллов методом молекулярно-пучковой эпитаксии (МПЭ) на $\mathrm{Si}$ $<111>$.

На рисунке продемонстрировано изображение синтезированных наноколонок фосфида галлия (GaP) на текстурированной $\mathrm{Si} / \mathrm{SiO}_{x}$ подложке, полученное методом сканирующей электронной микроскопии.

Работа была проведена при поддержке Российского научного фонда (проект № 21-7910346).

\section{Лuтература}

[1] A.Y. Liu et. al. // Optics letters. 2017. 42(2), pp.338-341.

[2] Q. Gao et al. // Nano letters. 2014. 14(9), pp.5206-5211.

[3] T. Schumann et al. // Nanotechnology. 2011. 22(9), p.095603. 